\title{
Occurrence of Tobacco streak virus on Peanut (Arachis hypogaea) in India
}

\author{
A. S. Reddy, International Crops Research Institute for the Semi-Arid Tropics (ICRISAT), Patancheru 502 324, An- \\ dhra Pradesh, India; R. D. V. J. Prasada Rao, National Bureau of Plant Genetic Resources, Rajendranagar, Hydera- \\ bad 500 030, Andhra Pradesh, India; K. Thirumala-Devi and S. V. Reddy, ICRISAT, Andhra Pradesh, India; M. A. \\ Mayo and I. Roberts, Scottish Crop Research Institute, Invergowrie, Dundee DD2 5DA, UK; T. Satyanarayana, \\ Citrus Research and Education Center, University of Florida, Lake Alfred 33850; K. Subramaniam, Agricultural \\ Research Station, Acharya N G Ranga Agricultural University, DCMS Buildings, Kamala Nagar, Ananthapur 515 \\ 001, Andhra Pradesh, India; and D. V. R. Reddy, ICRISAT, Andhra Pradesh, India
}

\begin{abstract}
Reddy, A. S., Prasada Rao, R. D. V. J., Thirumala-Devi, K., Reddy, S. V., Mayo, M. A., Roberts, I., Satyanarayana, T., Subramaniam, K., and Reddy, D. V. R. 2002. Occurrence of Tobacco streak virus on peanut (Arachis hypogaea) in India. Plant Dis. 86:173-178.

A virus disease of peanut (groundnut, Arachis hypogaea L.), characterized by necrosis of the stem and terminal leaflets followed by death, caused severe crop losses in Andhra Pradesh, India during the rainy season of the year 2000. The disease was referred to as peanut stem necrosis disease (PSND). Cowpea (Vigna unguiculata, cv. C-152) and Phaseolus vulgaris (cv. Topcrop) were found to be suitable for propagating the virus. In laboratory inoculation tests, the virus was found to infect a large number of plants. In laboratory tests, the virus was transmitted by the thrips Frankliniella schultzei. Virus particles were purified by differential centrifugation and sucrose density gradient centrifugation from infected cowpea plants and were used to elicit the production of a rabbit polyclonal antiserum with high titer. Extracts of infected plants reacted with antiserum to Tobacco streak virus (TSV). Analysis by sodium dodecyl sulfatepolyacrylamide gel electrophoresis of proteins extracted from purified virus particles showed them to contain a major protein of $28 \mathrm{kDa}$ and a minor, though prominent, protein of $57 \mathrm{kDa}$. Gel electrophoresis of RNA extracted from virus particles resolved it into four species with estimated sizes of 3.7, 3.1, 2.2, and $0.9 \mathrm{~kb}$. Complementary DNA (cDNA) was made using as template a sample of the 2.2-kb RNA 3 and as primer an oligonucleotide complementary to sequence in RNA 3 of TSV. Following second strand synthesis, the cDNA was cloned in pBluescript and the nucleotide sequence was obtained for $868 \mathrm{nt}$ of the cDNA. The sequence was $88.4 \%$ identical to the sequence in RNA 3 of TSV (strain WC). The results indicate that the causal agent of PSND is TSV. The same virus also was found to cause sunflower necrosis, an economically important disease in India. Studies on the epidemiology of PSND and the identification of virus-resistant peanut genotypes have been initiated to devise strategies to control PSND.
\end{abstract}

Additional keywords: Peanut bud necrosis virus

A virus disease was recorded in the year 2000 on peanut (groundnut, Arachis hypogaea L.) crops grown on nearly 225,000 ha in the state of Andhra Pradesh, India. Characteristic symptoms were necrosis of the stem and terminal leaflets followed by death of the plant. It was therefore referred to as peanut stem necrosis disease (PSND). Severe yield reduction was noticed from all infected plants and the majority of pods showed necrotic spots. Crop losses were estimated to exceed US\$65 million. Initially, the disease was assumed to be caused by the tospovirus Peanut bud necrosis virus (PBNV) because of the

Corresponding author: D. V. R. Reddy

E-mail: D.Reddy@cgiar.org

Accepted for publication 14 October 2001.

Publication no. D-2001-1217-03R

(C) 2002 The American Phytopathological Society characteristic necrosis of terminal leaflets (17). Axillary shoot proliferation and severe leaf deformity are characteristic symptoms of peanut bud necrosis disease (PBND). None of these symptoms were noticed in the case of PSND. Invariably, PSND-affected peanut plants died due to severe necrosis. PBND-affected plants seldom die due to the spread of terminal bud necrosis to other parts of the plant. Necrotic lesions observed on pods in the case of PSND were never recorded for plants affected by PBND. Many of the affected peanut fields were adjacent to sunflower fields which showed the symptoms of sunflower necrosis disease (13). Due to the economic importance of the disease and the fact that PSND appeared to be a hitherto undescribed virus disease of peanut, it was necessary to characterize the causal virus and devise strategies for its management.

In this article, we provide evidence that PSND is caused by the ilarvirus Tobacco streak virus (TSV), a new record on peanut in the Indian subcontinent.

\section{MATERIALS AND METHODS}

Virus isolate. The virus was collected from peanut fields in Ananthapur during the rainy season of the year 2000 and maintained by mechanical inoculations. Discrete lesions produced in a leaf of an inoculated cowpea plant were used as a source of a single lesion isolate. This isolate was used in all experiments described in this article.

Virus purification. Virus was purified from primary leaves of cowpea plants that showed necrotic spots and veinal necrosis. The tissue was homogenized in a Waring blender with four volumes ( $1 \mathrm{~g}$ per $4 \mathrm{ml})$ of $100 \mathrm{mM}$ potassium phosphate buffer, $\mathrm{pH}$ 8.0 , containing $0.75 \%$ monothioglycerol ( $\mathrm{vol} / \mathrm{vol})$ and $0.17 \%$ diethyldithiocarbamate $(\mathrm{wt} / \mathrm{vol})$. The extract was filtered through cheesecloth and chloroform was added to $10 \%(\mathrm{vol} / \mathrm{vol})$. After thorough mixing, the aqueous phase was separated by centrifugation at $6,000 \times g$ for $5 \mathrm{~min}$ and polyethylene glycol and $\mathrm{NaCl}$ were added to give concentrations of $8 \%$ (vol/vol) and $200 \mathrm{mM}$, respectively. After $90 \mathrm{~min}$, the mixture was centrifuged at $11,000 \times g$ and the pellet was resuspended in $150 \mathrm{ml}$ of $50 \mathrm{mM}$ potassium phosphate buffer, $\mathrm{pH} 8.0$, containing $0.2 \%$ Triton $\mathrm{X}$ 100 ( vol/vol) and clarified by centrifugation at $6000 \times g$ for $10 \mathrm{~min}$. The rest of the procedure, which included pelleting through a sucrose cushion and rate zonal density gradient centrifugation in sucrose solutions, was as described (15).

Antiserum production. Purified virus (100 to $150 \mu \mathrm{g}$ ), suspended in $0.3 \mathrm{ml}$ of 10 $\mathrm{mM}$ phosphate buffer, $\mathrm{pH}$ 8.0, was emulsified with an equal volume of Freunds' complete adjuvant for the first subcutaneous injection and with incomplete adjuvant for the subsequent five intramuscular or subcutaneous injections. Injections were given at weekly intervals in multiple sites to a New Zealand White inbred rabbit; 2 weeks after the last injection, the rabbit was bled at weekly intervals.

Enzyme-linked immunosorbent assay. Direct antigen coating (DAC) and double antibody sandwich (DAS) forms of enzyme-linked immunosorbent assay (ELISA) 
procedure were as described (7). Leaf extracts prepared in $50 \mathrm{mM}$ sodium carbonate buffer, $\mathrm{pH}$ 9.6, were used for coating the microtiter plates. Crude antisera were diluted at $1: 10,000$ or $1: 50,000$ and cross absorbed with extracts of healthy peanut leaves. Goat antirabbit immunoglobulins conjugated to alkaline phosphatase (Sigma-Aldrich, St. Louis) were used at a 1:5000 dilution of the commercial stock. The substrate was $p$-nitrophenyl phosphate at $1 \mathrm{mg} / \mathrm{ml}$. Absorbance was recorded at $405 \mathrm{~nm}$ after incubation for $1 \mathrm{~h}$ at room temperature following the addition of the substrate. For DAS-ELISA, immunoglobulin $\mathrm{G}(\mathrm{IgG})$ was used at $5 \mu \mathrm{g} / \mathrm{ml}$ for coating. IgG-alkaline phosphatase con-

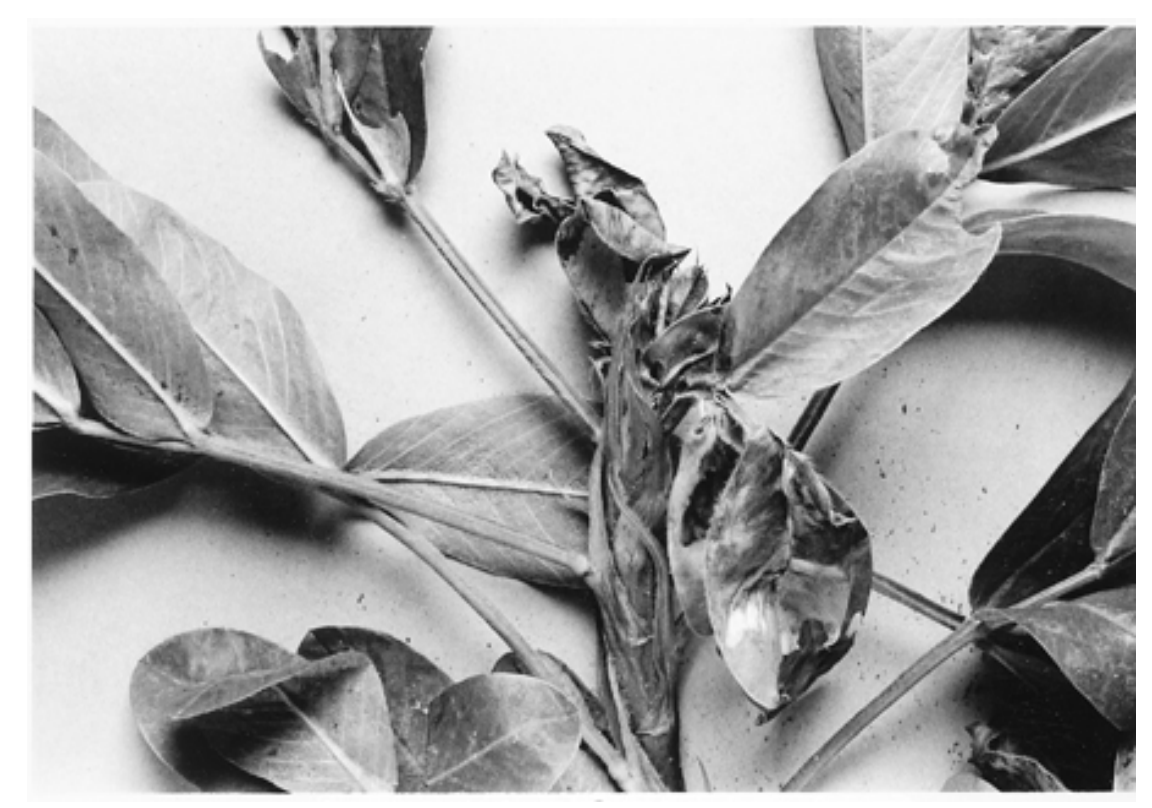

Fig. 1. Peanut plant, infected with the peanut stem necrosis isolate of Tobacco streak virus, showing necrosis of all the terminal leaflets.

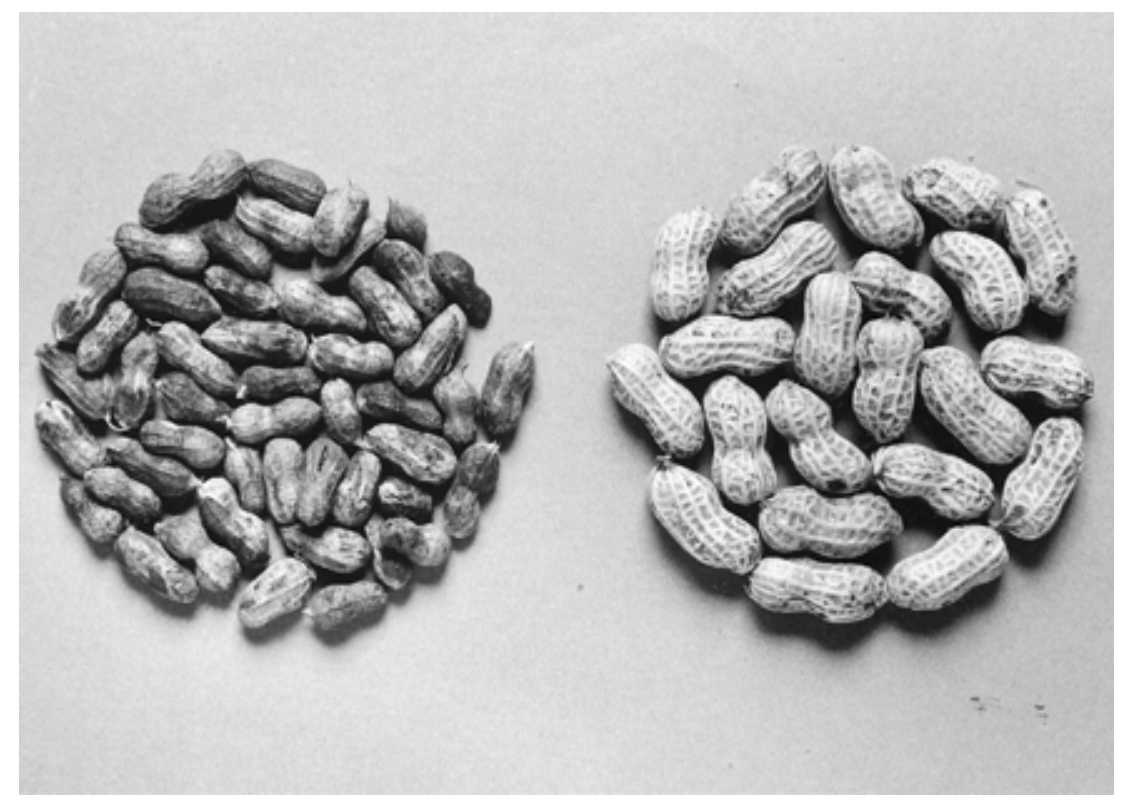

Fig. 2. Pods from peanut stem necrosis-diseased plants (left) compared with pods from healthy plants (right).

jugates were used at a dilution of 1:1,000. Various antisera for TSV (ATCC PVAS 276, A. T. Jones for black raspberry, and E. L. Halk) and Cucumber mosaic virus (CMV) strains CMV-B, CMV-C, and CMV-S (from George Thottappilly) were used to test serological relationships.

Host range studies. All plants were grown in a glasshouse at temperatures ranging from 25 to $30^{\circ} \mathrm{C}$. At least eight plants of each species were inoculated mechanically with sap extracts prepared in $10 \mathrm{mM}$ phosphate buffer, $\mathrm{pH} 7.0$, containing $0.75 \%(\mathrm{vol} / \mathrm{vol})$ mono-thioglycerol, and were maintained in a glasshouse for 8 weeks. Symptomatic and symptomless plants were tested by ELISA as described

174 Plant Disease / Vol. 86 No. 2
(7). Various weed plants were collected from peanut fields in the Ananthapur area and sap extracts from them were inoculated to cowpea plants. These were tested about 2 weeks later by ELISA for the presence of the virus.

Electron microscopy. Phaseolus vulgaris (cv. Topcrop) leaves were sent to Scotland soaked in $50 \%$ glycerol. They were washed for 1 to 2 days in buffer and triturated in $10 \mathrm{mM}$ phosphate buffer, $\mathrm{pH}$ 7.5, containing $0.2 \%$ glutaraldehyde ( $\mathrm{vol} / \mathrm{vol})$ and clarified by centrifugation at $1,000 \times g$. Immunosorbent electron microscopy (ISEM) was done essentially as described (20), using homologous antiserum or antiserum to TSV (a gift from E. L. Halk) by trapping for 1,2 , or $4 \mathrm{~h}$ at $4^{\circ} \mathrm{C}$. Grids were stained with uranyl acetate and virus particles were counted as described $(18,19)$.

Transmission by thrips. Frankliniella schultze $i$ adults were collected from peanut fields and reared on peanut plants (cv. JL24). Pollen was collected from virus-infected sunflower from the field in a petri dish on black paper by gently tapping the flowers. Fully expanded primary leaves of cowpea (cv. C-152) were dusted with pollen and 10 to 15 adult thrips were released immediately onto each plant, each of which was then covered individually with polystyrene cylindrical cages. After 1 day of exposure, thrips were killed by spraying plants with dimethoate. Plants were then maintained in a glasshouse at 28 to $32^{\circ} \mathrm{C}$ for a week. All exposed plants were indexed for virus infection by ELISA. Adult thrips also were exposed to young infected leaves of sunflower for 1 day, after which 10 to 15 adults were placed on each cowpea seedling for 1 day.

Sodium dodecyl sulfate-polyacrylamide gel electrophoresis and Western blotting. Sodium dodecyl sulfate-polyacrylamide gel electrophoresis (SDSPAGE) of purified virus was as described $(12,15)$. Virus preparations were solubilized in $10 \mathrm{mM}$ phosphate buffer, $\mathrm{pH} 8.0$, soon after purification. Markers consisted of recombinant proteins with $M_{\mathrm{r}}$ of 97.4, $68,43,29,18.4$, and $14.3 \mathrm{kDa}$, supplied by GIBCO (Life Technologies, Grand Island, NY). Gels were stained with Coomassie blue. For Western blots, polypeptides from purified virus preparations were electrophoretically blotted onto nitrocellulose (BA 83, 0.45- $\mu \mathrm{m}$ pore size; Schleicher and Schuell, Dassel, Germany) by using a semidry transfer unit (16) at $20 \mathrm{~V}$ for $1 \mathrm{~h}$. Both homologous and heterologous antisera were used at a 1:5,000 dilution. Goat antirabbit immunoglobulins conjugated to alkaline phosphatase were used at a $1: 1,000$ dilution of the commercial stock. The substrate was Fast Red TR/Naphthol AS-MX in $200 \mathrm{mM}$ Tris- $\mathrm{HCl}$ buffer, $\mathrm{pH}$ 8.3 (Sigma-Aldrich).

Nucleic acid analysis. Nucleic acid was extracted from purified virus preparations 
by treatment with phenol followed by phenol:chloroform (1:1 vol/vol). Extracted RNA was precipitated from the final aqueous phase by mixing it with ethanol to $70 \%$ ( $\mathrm{vol} / \mathrm{vol})$ and sodium acetate, $\mathrm{pH} \mathrm{5.2,} \mathrm{to}$ $300 \mathrm{mM}$ and storing at $-30^{\circ} \mathrm{C}$. RNA was collected by low speed centrifugation and stored at $-70^{\circ} \mathrm{C}$ in diethyl pyrocarbonatetreated water. Samples were analyzed in $1.0 \%$ agarose gels containing $10 \mathrm{mM}$ methyl mercuric hydroxide (1).

Complementary DNA synthesis and cloning. RNA 3 was isolated from lowmelting agarose gels. First-strand complementary DNA (cDNA) synthesis was done using as primers a TSV-specific oligonucleotide downstream primer (5'AACGAC GCC TTCGCTTGAGG $3^{\prime}$ ) and an upstream primer (5'AGTTGGACGCTATGGCCAGG 3') designed to amplify the 169bp fragment between nucleotides 1304 and 1472 of RNA 3 of TSV (S. Scott, personal communication) or random hexanucleotide and avian myeloblastosis virus reverse transcriptase. Second-strand cDNA was synthesized using the Universal Riboclone synthesis system (Promega, Southampton, $\mathrm{UK}$; 6). After the second-strand synthesis, the resulting products were cloned into Sma 1-cut pBluescript and transformed into Escherichia coli competent cells (Promega). Plasmids were extracted from the recombinant clones by using the QIA Miniprep kit (Qiagen Ltd., West Sussex, UK). They were confirmed as recombinant by digestion with $\mathrm{Xbal}$ and EcoRI and electrophoresis in $1 \%$ agarose gels.

Nucleotide sequencing and computer analysis. The nucleotide sequences of cDNA inserts in the recombinant clones were determined by dideoxy nucleotide chain termination using the Dye-prism cycle sequencing kit (Applied Biosystems, Warrington, UK) using both M13 forward and reverse primers.

\section{RESULTS}

Symptomatology and host range. Initial symptoms on peanut appeared 1 week after inoculation. Young leaflets showed large necrotic lesions. These coalesced and, 2 weeks after inoculation, the entire quadrifoliate was necrotic. This stage was followed by necrosis of the stem (Fig. 1) and, by 3 weeks after inoculation, the entire plant was necrotic. In field infections, characteristic symptoms were necrosis of one or more terminal leaflets and stem necrosis. Necrotic spots were observed on the majority of pods (Fig. 2). Plants were severely stunted and yields of peanuts from these plants were much less than from control plants, even when symptoms were observed only after the peg formation (i.e., late infection).

Hosts infected by mechanical inoculation are given in Table 1. Cowpea cv. C152 (Fig. 3) and P. vulgaris cv. Topcrop were found to be suitable for propagating the virus. The following plants were not infected in these tests: Brassica campestris cv. Green herd, Capsicum annum cv. Pusa Jwala, Nicotiana hybrid (N. glutinosa $\times N$. clevelandii), N. tabacum cv. Xanthi-nc, Lycopersicon esculentum cvs. Pusa Ruby and Maruthi, Pisum sativum cv. Bonneville, Raphanus sativus, and Spinacia oleracea.

Purification. After sedimentation in sucrose gradients for $90 \mathrm{~min}$ at $90,000 \times \mathrm{g}$, two light-scattering zones were observed at 50 to $56 \mathrm{~mm}$ and 58 to $64 \mathrm{~mm}$ from the bottom of Beckman SW 28 tubes. Cowpea

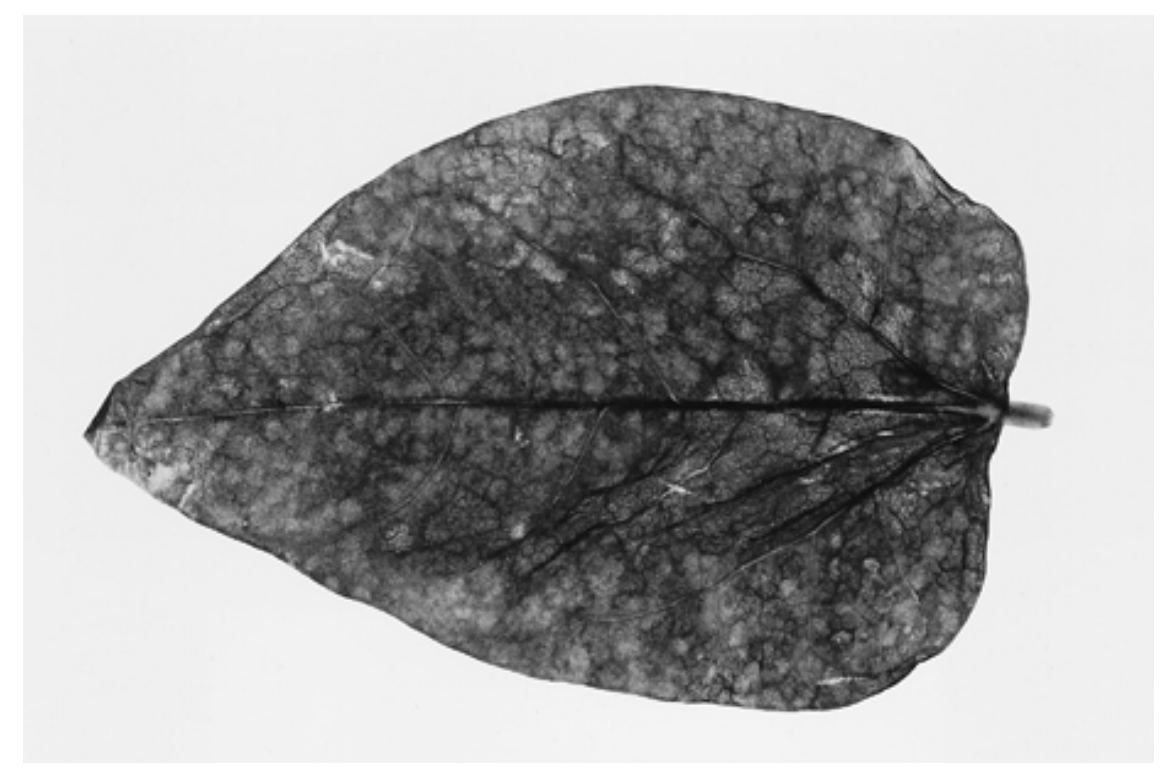

Fig. 3. Cowpea (cv. C-152) inoculated with the peanut stem necrosis isolate of Tobacco streak virus.

Table 1. Reaction of various hosts to an isolate of Tobacco streak virus from peanut

\begin{tabular}{|c|c|c|}
\hline \multirow[b]{2}{*}{ Host species } & \multicolumn{2}{|c|}{ Symptoms $^{\mathbf{a}}$} \\
\hline & Primary & Systemic \\
\hline Cajanus cajan cv. ICP 8863 & NL & $\mathrm{TN}$ of leaves and stem \\
\hline Cicer arietinum cv. WR 315 & NL & $\mathrm{TN}$ of leaves and stem \\
\hline Crotalaria juncea & CL & $\mathrm{TN}$ of leaves and stem \\
\hline Chenopodium quinoa & CL & $\mathrm{TN}$ of leaves \\
\hline C. amaranticolor & CL & $\mathrm{TN}$ of leaves and stem \\
\hline C. murale & CL & $\mathrm{CL}$ \\
\hline Cyamopsis tetragonaloba cv. S-51 & & NL \\
\hline Datura stramonium & SL & MO \\
\hline Glycine max cv. Bragg & CL & $\mathrm{TN}$ of leaves and stem \\
\hline Gossypium hirsutum cv. LRA 5160 & CL & $\mathrm{LC}$ \\
\hline Gomphrena globosa & CL & $\mathrm{VN}$ \\
\hline Helianthus annus cv. MSFH 8 & CL & TN of leaves and stem \\
\hline Nicotiana benthamiana & CL & MO \\
\hline N. glutinosa & $\mathrm{VC}$ & $\mathrm{VC}$ \\
\hline N. rustica & CL & VN \\
\hline N. tabacum cv. White burley & CL & MO \\
\hline N. tabacum cv. Havana & $\mathrm{CL}$ & $\mathrm{TN}$ of leaves \\
\hline N. tabacum cv. Turkish & $\mathrm{CL}$ & $\mathrm{CL}$ \\
\hline N. tabacum cv. Samsun & $\mathrm{CL}$ & $\mathrm{VN}$ \\
\hline Phaseolus vulgaris cv. Topcrop & $\mathrm{NL}, \mathrm{VN}$ & $\mathrm{TN}$ of leaves and stem \\
\hline Physalis floridana & CL & $\mathrm{TN}$ of leaves and stem \\
\hline Tagetus erecta & NL & NL \\
\hline Trigonella foenum & NL & $\mathrm{VN}$ of leaves \\
\hline Vicia faba cv. VH 82-1 & NL & NL \\
\hline Vigna unguiculata cv. C-152 & NL, VN & $\mathrm{TN}$ of leaves and stem \\
\hline V. mungo cv. UPU-1 & NL & TN of leaves and stem \\
\hline V. radiata $\mathrm{cv} . \mathrm{Hy}-45$ & NL & $\mathrm{TN}$ of leaves and stem \\
\hline
\end{tabular}

a Source for mechanical inoculations was peanut, virus infection confirmed in enzyme-linked immunosorbent assay tests. $\mathrm{CL}=$ chlorotic lesions, $\mathrm{LC}=$ leaf curling, $\mathrm{MO}=$ mosaic symptoms, $\mathrm{NL}=$ necrotic lesions, $\mathrm{SL}=$ symptomless, $\mathrm{TN}=$ total necrosis, $\mathrm{VC}=$ veinal chlorosis, and $\mathrm{VN}=$ veinal necrosis. and peanut plants that were inoculated with collected from either zone developed symptoms. Systemically infected of purified virus, assuming an extinction coefficient of

$$
\sum_{1 \mathrm{~cm} .260}^{-0.1 \%}=7.0
$$

Serological relationships. Two TSV antisera were used in DAC- and DAS-ELISA tests: TSV (ATCC-PVAS 276) and antise- 
Table 2. Comparison in direct antigen coating (DAC)- and double antibody sandwich-enzymelinked immunosorbent assay (DAS-ELISA) tests of Tobacco streak virus (TSV) isolates from peanut with two TSV and three Cucumber mosaic virus antisera ${ }^{\mathrm{a}}$

\begin{tabular}{lccc}
\hline & \multicolumn{3}{c}{ Antisera for TSV $^{\mathbf{b}}$} \\
\cline { 2 - 4 } ELISA, dilution & Homologous & ATCC & Black raspberry \\
\hline DAC: TSV from peanut & 2.42 & 2.20 & 2.12 \\
$10^{-2}$ & 1.93 & 1.42 & 1.52 \\
$10^{-3}$ & 0.99 & 0.43 & 0.58 \\
$10^{-4}$ & 0.51 & 0.07 & 0.09 \\
$10^{-5}$ & 1.82 & 1.52 & 1.60 \\
DAC: TSV from cowpea & 1.46 & 0.61 & 0.71 \\
$10^{-2}$ & 0.72 & 0.21 & 0.32 \\
$10^{-3}$ & 0.39 & 0.02 & 0.04 \\
$10^{-4}$ & & & \\
$10^{-5}$ & 1.18 & 0.99 & 1.20 \\
DAS: TSV from peanut & 0.62 & 0.58 & 0.70 \\
$10^{-2}$ & 0.41 & 0.40 & 0.41 \\
$10^{-3}$ & 0.23 & 0.22 & 0.25 \\
$10^{-4}$ & & & \\
$10^{-5}$ & & & \\
\hline
\end{tabular}

${ }^{a}$ For DAC, all antisera were cross absorbed with peanut leaf extracts. For DAS, enzyme conjugates were cross absorbed with peanut leaf extracts.

${ }^{b}$ All values are average of three replications and deducted from absorbance for healthy plants.

${ }^{c}$ Dilution of plant extract.

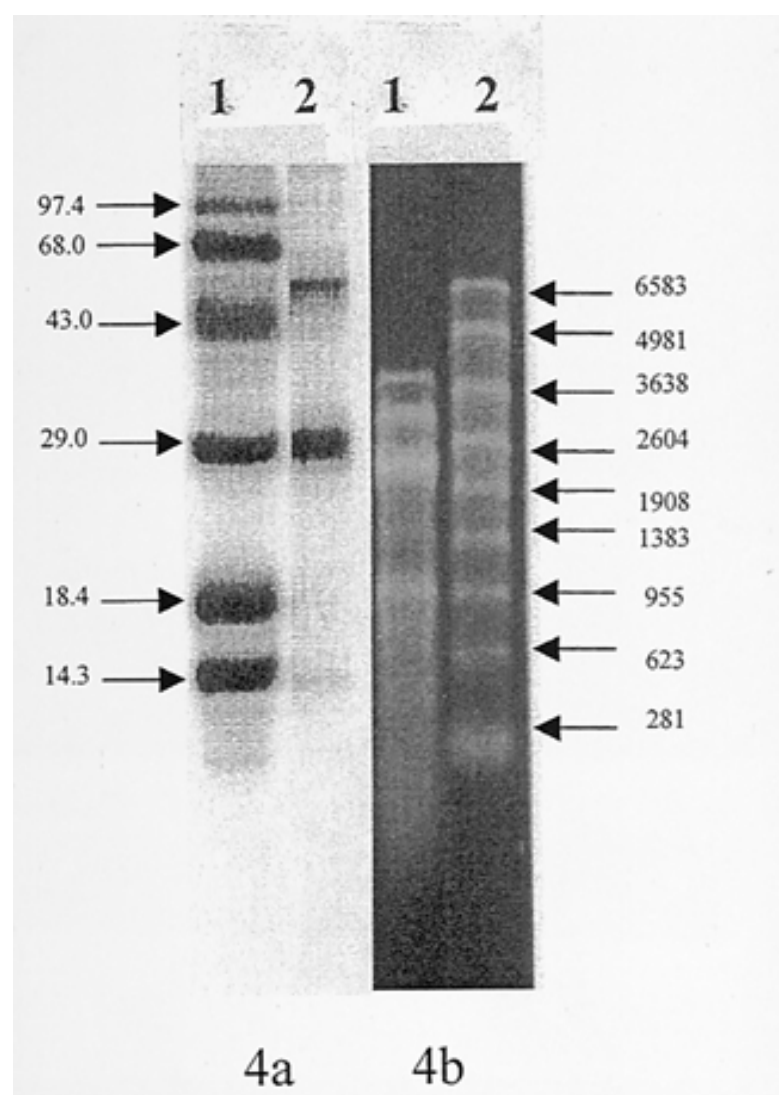

Fig. 4. A, Western blots of purified virus preparations. Proteins were separated by sodium dodecyl sulfate-polyacrylamide gel electrophoresis, transferred to nitrocellulose membranes, and reacted with homologous antiserum. Lane 1: protein markers of 97.4, 68, 43, 29, 18.4, and $14.3 \mathrm{kDa}$; lane 2: purified virus showing 28- and 57-kDa polypeptides. B, Lane 1: gel electrophoresis of Tobacco streak virus RNA after denaturation with methyl mercuric hydroxide. Lane 2: RNA size markers of 6,583, $4,981,3,638,2,604,1,908,1,383,955,623$, and $281 \mathrm{nt}$. The gel was stained with ethidium bromide.

rum to TSV (black raspberry isolate). In DAC-ELISA, the virus in crude plant extracts and purified virus preparations reacted strongly with the homologous antiserum and with antisera to TSV. Maximum reaction was obtained with the homologous the two TSV antisera. Virus isolated from two hosts essentially gave similar cross reactions (Table 2). There was no reaction in DAC-ELISA with antisera to CMV-B, CMV-C, and CMV-S isolates.

The virus from both the sucrose zones contained one major polypeptide of 28 $\mathrm{kDa}$. All preparations also contained a minor polypeptide of $57 \mathrm{kDa}$ (average of five determinations). Both proteins reacted in Western blots with homologous and two TSV antisera (Fig. 4A).

Electron microscopy. Preliminary tests showed the presence of numerous quasispherical virus-like particles in the extracts. These particles appeared to be distorted and had diameters ranging from 25 to $35 \mathrm{~nm}$, and their general condition was poor in a range of negative stains. Particle condition was improved by using leaf material that had been stored in $50 \%$ glycerol in transit (19) and extracted in buffer containing glutaraldehyde (Fig. 5). Particle counts from ISEM tests showed that the homologous antiserum and TSV antiserum (from E. L. Halk) trapped a large numbers of virus particles when compared with control grids (Table 3 ).

Transmission. Typical veinal necrosis symptoms were observed on cowpea plants 3 days after exposure of $F$. schultzei onto leaves dusted with pollen from infected plants (Table 4). Thrips fed on infected leaves alone did not transmit the virus. All the symptomatic plants contained the virus, as determined by ELISA.

Virus nucleic acid. Nucleic acid extracted from purified virus particles contained four RNA species that had apparent sizes of $3.7,3.1,2.2$, and $0.9 \mathrm{~kb}$ when analyzed by electrophoresis in denaturing gels. In some preparations, RNA components of 0.6 and $0.42 \mathrm{~kb}$ were also observed (Fig. 4B). The concentration of the RNA 3 was greater than that of the other three RNA species.

Nucleotide sequencing. Fourteen clones were selected for sequencing. Sequence was obtained by priming reactions in the pBluescript sequence on either side of the inserted cDNA. Two regions of sequence were obtained that overlapped. Comparison with database sequences using BLAST showed strong similarity between the observed sequence and that of RNA 3 of TSV (WC strain) (EMBL:TOTSV3). Over the entire sequenced portion ( $868 \mathrm{nt})$, the sequence identity was $88.4 \%$. The sequence corresponded to the $3^{\prime}$ terminal part of the movement protein and the $5^{\prime}$ terminal part of the coat protein of TSV. The identities were $89 \%$ in the movement protein gene (from 526 of a probable total of 870 nucleotides) and $85 \%$ in the coat protein gene (from 219 of a probable total of 714 nucleotides).

In DAC-ELISA, differences the reaction between the antisera were apparent only at high dilutions of plant extracts. However, in the DAS form of ELISA, no differences in cross reaction were noted between the homologous and

\section{DISCUSSION}

The results show that PSND is caused by an isolate of TSV. The identification 


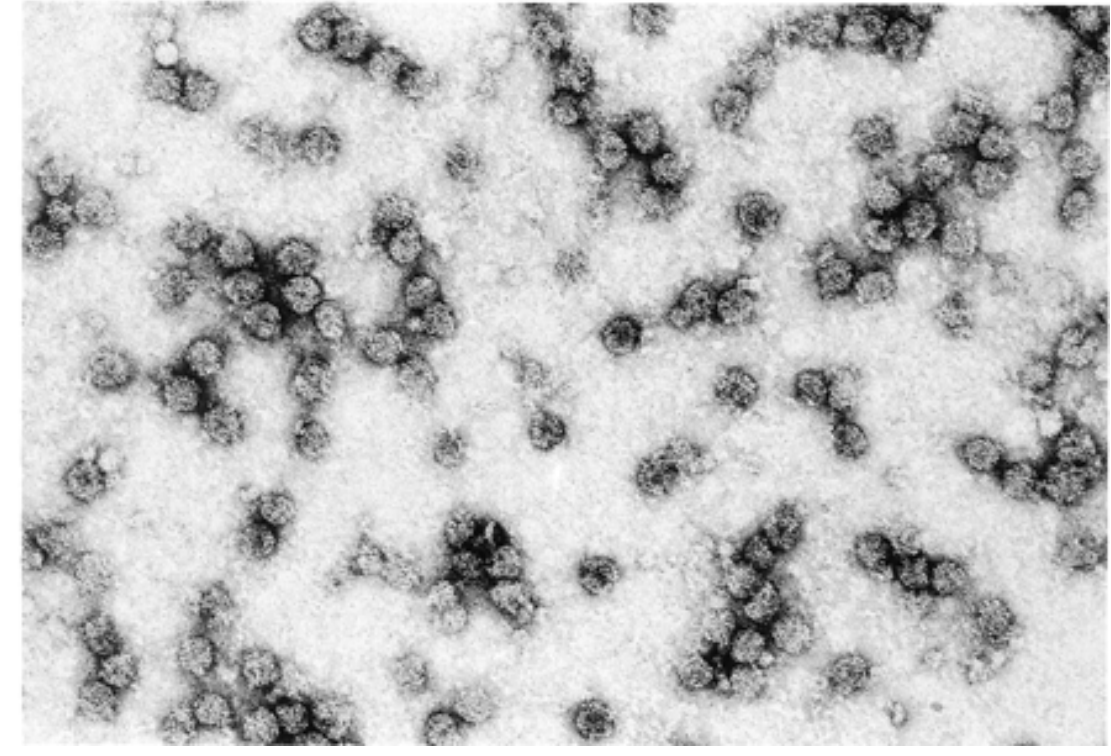

Fig. 5. Particles of the peanut stem necrosis isolate of Tobacco streak virus stained with $1 \%$ uranyl acetate. Particles were trapped from extracts of leaves of infected Phaseolus vulgaris by using homologous antiserum. Magnification: $\times 140,000$.

Table 3. Immunosorbent electron microscopy of Phaseolus vulgaris (cv. Topcrop) leaf extracts infected with a peanut isolate of Tobacco streak virus (TSV)

\begin{tabular}{llll}
\hline & \multicolumn{3}{c}{ Particle counts/ $\mathbf{u m}^{\mathbf{2 a}}$} \\
\cline { 2 - 4 } Antiserum $^{\mathbf{b}}$ & Grid 1 & Grid 2 & Mean \\
\hline Homologous & 34.7 & 34.8 & 34.75 \\
TSV & 51.4 & 49.6 & 50.5 \\
Controls & 2.7 & 2.9 & 2.8 \\
\hline
\end{tabular}

${ }^{\mathrm{a}}$ Counts were from grids that had been coated with diluted antiserum and allowed to trap virus for $2 \mathrm{~h}$ at $4^{\circ} \mathrm{C}$, then stained with $1 \%$ aqueous uranyl acetate.

b TSV from E. L. Halk; control grids were uncoated carbon-filmed grids left to trap virus for the same length of time.

was made on the basis of serological reaction, sizes of coat protein and nucleic acid species, similarity of nucleotide sequences of parts of RNA 3, mode of transmission by thrips, and particle morphology. This is also the first record of TSV in peanut (13) from India. An ilarvirus was recorded on sunflower recently (14) but it was not fully characterized. This is also the first record of TSV infection of peanut crops under field conditions. Peanut was recorded as a host for TSV (4) on the basis of a report by Gracia and Feldman (5). However, peanut was not listed among TSV hosts in that report.

Severe necrosis by TSV was recorded as a characteristic host response of many plants under glasshouse conditions (25 to $\left.30^{\circ} \mathrm{C}\right)$. The virus differed from the isolates reported by Fulton (3) and those on pepper (5) and soybeans (2) in not infecting $L$. esculentum, $P$. sativum and $N$. tabacum cv. Xanthi-nc. Additionally, characteristic streak and necrotic symptoms reported on tobacco were not observed for the peanut isolate. Host range studies and symptoms
Table 4. Transmission of Tobacco streak virus from sunflower by Frankliniella schultzei

\begin{tabular}{lcc}
\hline & \multicolumn{2}{c}{ Transmission tests $^{\mathbf{a}}$} \\
\cline { 2 - 3 } Experiment & Pollen $^{\mathbf{b}}$ & Thrips $^{\mathbf{c}}$ \\
\hline 1 & $7 / 10$ & $0 / 10$ \\
2 & $5 / 12$ & $0 / 12$ \\
\hline
\end{tabular}

${ }^{a}$ In all, 10 to 15 adult thrips were used for each cowpea seedling. Exposure of thrips was for 1 day. Number of infected plants/numbers tested.

${ }^{\mathrm{b}}$ Pollen from virus-infected sunflower was dusted onto primary leaves of cowpea seedlings, after which the adult thrips were placed on the leaf. All symptomatic plants were confirmed for virus presence by enzyme-linked immunosorbent assay.

c Adult thrips were exposed to infected sunflower leaves for 1 day, then placed on the primary leaf of cowpea seedlings.

were used to group five isolates of TSV $(10,11)$. On the basis of the symptoms observed on Chenopodium amaranticolor, $C$. quinoa, and $V$. unguiculata, the peanut isolate can be grouped under those described for "pathotype 1". Unlike the isolate from peanut, all three isolates in pathotype I did not infect $N$. tabacum $\mathrm{cv}$. Havana 423. Unlike SB-10, an isolate from potato (21), the peanut isolate infected Datura stramonium.

All the antisera used in DAC-ELISA tests were cross absorbed with healthy plant extracts. The serum obtained from ATCC, which was produced for TSV-WC, reacted strongly with the peanut isolate. Presumably, the antiserum was produced for one of the TSV isolates in pathotype I. Antisera obtained for the isolates from black raspberry (9) and from E. L. Halk reacted with the peanut isolate in DAC as well as DAS forms of ELISA. A slight difference in the cross reaction was ob- served in DAC-ELISA tests but not in DAS or ISEM tests. Additional tests, especially using monoclonal antibodies and nucleotide sequencing of RNA 3, are necessary to determine relationships between the peanut isolate and other TSV isolates.

Pollen from virus-infected plants was essential for thrips transmission. The transmission is apparently through wounding of leaf tissues by the thrips and is similar to that reported by Sdoodee and Teakle (22) for TSV. So far, F. schultzei has not been recorded to transmit TSV. Megalurothrips usistatus is a flower thrips often found to carry more than 75 pollen grains per thrips. Experiments are underway to test the efficiency of $M$. usistatus in transmitting TSV.

The symptoms of infection by TSV have been confused with those caused by PBNV. As a result, the epidemic caused by TSV during the 2000 growing season was attributed to PBNV. Although PBNV was implicated in the etiology of sunflower necrosis disease $(8,23)$, it has been demonstrated conclusively that sunflower necrosis is caused by TSV (13). Therefore, identification of infection by TSV or PBNV should not be based solely on observation of necrotic symptoms.

\section{ACKNOWLEDGMENTS}

We thank J. M. Lenné for encouragement and financial support; A. T. Jones (SCRI, Scotland) and G. Thottappilly (India) for the supply of antisera; S. Scott for TSV primers and primer sequences; and the Scottish Executive Rural Affairs Department for its support of M. A. Mayo and I. Roberts.

\section{LITERATURE CITED}

1. Bailey, J. M., and Davidson, N. 1976. Methylmercury as a reversible denaturing agent for agarose gel electrophoresis. Anal. Biochem. 70:75.

2. Fagbenle, H. H., and Ford, R. E. 1970. Tobacco streak virus isolated from soybeans, Glycine max. Phytopathology 60:814-820.

3. Fulton, R. W. 1948. Hosts of tobacco streak virus. Phytopathology 38:421-428.

4. Fulton, R. W. 1985. Tobacco streak virus. Pages 1-5 in: CMI/AAB Descriptions of Plant Viruses. No. 307. Assoc. of Appl. Biol., Kew, Surrey, England.

5. Gracia, O., and Feldman, J. M. 1974. Tobacco streak virus in pepper. Phytopathol. Z. 80:313-323.

6. Gubler, U., and Hoffman, B. J. 1983. A simple and very efficient method for generating cDNA libraries. Gene 25:263-269.

7. Hobbs, H. A., Reddy, D. V. R., Rajeswari, R., and Reddy, A. S. 1987. Use of direct antigen coating and protein A coating ELISA procedures for detection of three peanut viruses. Plant Dis. 71:747-749.

8. Jain, R. K., Bhat, A. I., Byadgi, A. S., Nagaraju, Harvir Singh, Halkeri, A. V., Anahosur, K. H., and Varma, A. 2000. Association of tospovirus with sunflower necrosis disease Curr. Sci. 79:1703-1705.

9. Jones, A. T., and Mayo, M. A. 1975. Further properties of black raspberry latent virus, and evidence for its relationship to tobacco streak virus. Ann. Appl. Biol. 79:297-306.

10. Kaiser, W. J., Wyatt, S. D., and Klein, R. E. 1991. Epidemiology and seed transmission of two tobacco streak virus pathotypes associated with seed increases of legume 
germplasm in eastern Washington. Plant Dis. 75:258-264

11. Kaiser, W. J., Wyatt, S. D., and Pesho, G. R. 1982. Natural hosts and vectors of tobacco streak virus in Eastern Washington. Phytopathology 72:1508-1512.

12. Laemmli, U. K. 1970. Cleavage of structural proteins during the assembly of the head of bacteriophage T4. Nature 277:680-685.

13. Prasada Rao, R. D. V. J., Reddy, A. S., Chander Rao, A. S., Varaprasad, K. S., Thirumala Devi, K., Nagaraju, Muniyappa, V., and Reddy, D. V. R. 2000. Tobacco streak ilarvirus as a causal agent of sunflower necrosis disease in India. J. Oilseeds Res. 17:400-401.

14. Ramaiah, M., Bhat, A. I., Jain, R. K., Pant, R. P., Ahlawat, Y. S., Prabhakar, K., and Varma, A. 2001. Isolation of an isometric virus causing sunflower necrosis disease in India. Plant Dis. 85:443.

15. Reddy, D. V. R., Ratna, A. S., Sudarshana, M. R., Poul, F., and Kirankumar, I. 1992.
Serological relationships and purification of bud necrosis virus, a tospovirus occurring in peanut (Arachis hypogaea L.) in India. Ann. Appl. Biol. 120:279-286.

16. Reddy, D. V. R., Robinson, D. J., Roberts, I. M., and Harrison, B. D. 1985. Genome properties and relationships of Indian Peanut clump virus. J. Gen. Virol. 66:2011-2016.

17. Reddy, D. V. R., Sudarshana, M. R., Ratna, A. S., Reddy, A. S., Kiran Kumar, I., and Murthy, A. K. 1990. The occurrence of Yellowspot virus, a new member of tomato spotted wilt virus group, on peanut (Arachis hypogea L.) in India. Pages 77-83 in: Virus-Thrips-Plant Interactions of Tomato Spotted Wilt Virus, Proc. USDA Workshop. H. T. Hsu and R. H. Lawson, eds. U.S. Dep. Agric., MD.

18. Roberts, I. M. 1980. A method for providing comparative counts of small particles in electron microscopy. J. Microsc. 118:241-245.

19. Roberts, I. M. 1986. Practical aspects of handling, preparing and staining samples contain- ing plant virus particles for electron microscopy. Pages 213-413 in: Developments and Applications in Virus Testing. R. A. C. Jones and L. Torrance, eds. The Lavenham Press, Suffolk, UK.

20. Roberts, I. M. 1986. Immunoelectron microscopy of extracts of virus-infected plants. Pages 293-357 in: Electron Microscopy of Proteins: 5 Viral Structure. J. R. Harris and R. W. Horne, eds. Academic Press, London.

21. Salazar, L. F., Abad, J. A., and Hooker, W. J. 1982. Host range and properties of tobacco streak virus from potatoes. Phytopathology 72:1550-1554.

22. Sdoodee, R., and Teakle, D. S. 1987. Transmission of tobacco streak virus by thrips tabaci; a new method of plant virus transmission. Plant Pathol. 36:377-380.

23. Venkata Subbaiah, K., Sai Gopal, D. V. R. and Krishna Reddy, M. 2000. First report of Tospovirus on sunflower (Helianthus annus L.) from India. Plant Dis. 84:1343. 